\title{
Translation of the Sense and Form of the Language Play in R. Dahl's James and the Giant Peach
}

\author{
Trisnowati Tanto \\ English Department \\ Maranatha Christian University \\ Bandung, Indonesia \\ trisnowatitanto@gmail.com
}

\begin{abstract}
In the process of translation, ideally speaking, translators have to put into consideration both the form and the sense of the words. The form deals with the style or the construction of the words in the target language, while the sense deals with the content or the meaning of the words. Problems may occur when it comes to the translation of both the form and the sense as this very often cannot be done. In this case, translators will be faced with some alternatives: (1)to keep the form or the sense or (2)the form and the sense or (3)neither the form nor the sense. When the form is not well translated, the entertaining function will not work well. When the sense is not kept in the translation, the core of the story will not be accurate as told in the original story. The paper discusses the language play found in Roald Dahl's children's novel James and the Giant Peach, first published in $\mathbf{1 9 6 1}$ and its translation in Indonesian found in James dan Persik Raksasa, which was published by PT. Gramedia Pustaka Utama in 2010. Language play itself is language used mainly for entertaining function; hence, a writer usually exploits or manipulates the linguistic features. In the source language, Dahl uses a great variety of language play forms, covering the phonological, morphological, and semantic language plays. However, due to space constraints, the paper will focus on the phonological language play only. The phonological play involves the use of alliteration, consonance, assonance, onomatopoeia, and rhyme, which all contribute to the fact that language wise, this novel is highly entertaining. In the translated version, most of the data show that the translator mostly keeps the form and the sense, which is something exceptional, considering that the English and Indonesian languages are two distinct languages, whose forms are almost impossible to compare, let alone to translate. However, the translator's chosen strategies result in the fact that the enjoyment of reading the novel in the translated version can still rely on both the story itself and the novelist's creativity in playing with the language, as they are transferred quite well to the readers.
\end{abstract}

Keywords—translation; language play; sense; form; enjoyment

\section{INTRODUCTION}

Roald Dahl's witty and creative use of language in writing his novels and short stories, especially those for children, is definitely unquestionable. This is also beneficial for children because witty and creative language can arouse children's curiosity and imagination, not to mention their intelligence. His well known children's novels, to mention just a few, are
Charlie and the Chocolate Factory, Matilda, The Witches, The $B F G$, James and the Giant Peach, and many more. They have been translated into many languages and become best sellers all over the world, which is mainly due to the amazing fantasies experienced by the characters and the humorous and witty way of describing them all.

When amazing stories like Dahl's, which rely much on the storyline as well as the language features, are translated into another language, the translator must find it urgent to pay attention to both the word meaning and the word form. Eliminating one of them will surely cause the story to be inaccurate or the writer's writing style to no longer be obvious. This in the end will lead the reader to enjoy the novel as a whole much less.

Previous studies on the translation of language play focus more on the translation of puns. Some translation strategies for puns are suggested, namely "the translation of the source language pun by a target language pun; the rendering of the pun with another rhetorical device; the insertion of a compensatory pun where there was none in the source language" (Delabastita, as cited by Ushurova, 2013, p. 9). These strategies obviously emphasize on the importance of not eliminating the special and witty forms of language in the TL; on the contrary, these forms should be maintained in the TL as well as possible, as long as the puns are intentionally made in the SL.

Ushurova (2013) discusses how a translator translates wordplay in subtitling in one episode of a television series, focusing more on the translation of puns in the SL (English) which do not have equivalents in the TL (Dutch). Since the puns in the series are intended to produce humor, the findings show that "whenever possible, translators seem to take humor into account" (p. 17). However, as far as subtitling process is concerned, there are some limitations in space and time as well as the limited knowledge of culturally-specific expressions. This leads to the fact that "there have been no striking or conclusive findings" (p. 20) so that "... the specific functioning of wordplay has yet to be defined" (p. 20).

The forms of language play found in James and the Giant Peach are not restricted to puns only. There are also forms of phonological, morphological, and semantic plays, although 
this paper focuses only on the phonological play in the forms of sound repetition such as alliteration, consonance, assonance, onomatopoeia, and rhyme. Since the novel is intended for children, the sound repetition forms are definitely intentionally written and as such, they are worth translating by keeping both the sense and the form.

One of Dahl's children's novels is James and the Giant Peach, which was first published in 1961. This novel is about fantastic adventures of a poor orphan named James Henry Totter. He lives with his two mean and annoying aunts, who always mock and beat him. They often leave him starving and make his life miserable. His life changes drastically when one day he meets a mysterious old man who gives him a bag of magical seeds. After that his life is full of exciting and wonderful adventures as he travels with his new strange friends in a giant peach.

In terms of the language used, the novel abounds in words that play with extraordinary sounds, interesting word formation, and semantic contradictions. The fact may lead to a problem when this kind of work is translated into another language. The translator must put into consideration not only how to translate the sentences based on the meaning or sense, but also how to translate the style of writing or the form.

James and the Giant Peach was translated into Indonesian by Poppy D. Chusfani and published by PT. Gramedia Pustaka Utama in 2010. This paper aims to find out what the translator's strategies are in translating the novel, especially the parts containing the language play forms, which are in fact almost impossible to translate equivalently. Seeing that this is not a simple job to do, it is worthwhile to examine whether the translator has succeeded in keeping the sense as well as the form so as to keep both the meaning and style of the source text.

The paper is significant as it will give a better understanding about language play, which is necessary, as these interesting language features can make a novel much more enjoyable to read. For translators, they will have an insight about the importance of language play. Besides, the paper can be beneficial as translators can be made aware that in translating language play forms, they should think of the best strategy so that they can, ideally speaking, translate not only the word sense but also the word form.

\section{THEORETICAL REVIEW AND METHODOLOGY}

\section{A. Language Play}

Language play is language having the playful or ludic function, which is important so that people can appreciate language as a whole (Crystal, 1998, p. 1). In creating language play, "... some linguistic features-such as a word, a phrase, a sentence, a part of a word, a group of sounds, a series of letters - and [we] make it do things it does not normally do. We are, in effect, bending and breaking the rules of language. ... for fun" (Crystal, 1998, p. 1). For example, in the following joke, the word 'baaad' imitates the sound of sheep.

'Doctor, doctor, I've just swallowed a sheep!'

'How do you feel?'

'Very baaad.' (Crystal, 1998, p. 13)
Moreover, the definition of language play is made more complete by adding some other language features other than those with the bending and breaking of the language rules. Some repetitive forms of language features such as sound, word, and clause repetitions are also categorized into language play since "...they are there to be exploited to our advantage in many areas of human activity, including language learning", (Cook, 2000, p. 5). These forms of language play are referred to as "exploitation of formal patterns" (Cook, 2000, p. 122). Cook (2000, p. 227) further specifies that language play is divided into two types, namely play with language forms, such as the sounds of language (rhyme, rhythm, alliteration, assonance, anaphora, parison, etc.) and play with units of meaning. For example, in the similes 'as cracked as a crab', 'as dotty as a doughnut' found in Dahl's novel, Charlie and the Great Glass Elevator, or 'bald as a boiled egg' in Dahl's The Witches, there is a sound play in the form of an alliteration as the consonant sounds $/ \mathrm{kr} /, / \mathrm{d} /$, and $/ \mathrm{b} /$ are repeated. Besides, these similes also play with units of meaning as well because these similes are not the common ones people know. However, the meaning of the similes can be perfectly understood (Tanto, 2010, p. 42). This is in line with the opinion that "readers know exactly what to do when a certain convention is violated since they will search for a context that will make the violation comprehensible. When the search for context in making sense of the violation is successful, they will understand it. Otherwise, the message will fail to be conveyed when the search turns out to be a failure" (McQuarrie \& Mick, 1996, pp. 425-426).

\section{B. Translation}

There are two important points in translation, which are "equivalence between items in Source Language (SL) and Target Language (TL) and the notion of translatability" (Jakobson, as cited in Hatim \& Munday, 2004, p. 7). Furthermore, in the translating process, anything can be conveyed in any existing language although it may need some strategies to do that properly. Nevertheless, he also says that "by definition only poetry cannot be translated because in poetry the word form often constructs meaning" (ibid., p. 10), which leads to the fact that in translating there are two points to consider, namely the sense/content, which is always translatable, and the form/style, which is often untranslatable.

The problem above most probably appears when translating poems, songs, advertisement taglines or slogans, in which such forms as rhymes or puns, which are also categorized as forms of language play, are very unlikely to be translated in the TL. Thus, in this case a translator can use several strategies in the translating process so as to get the best translation. He has the options to (1) keep the form only, or the sense only, or (2) both the form and the sense, or (3) neither the form and the sense. The most ideal is definitely keeping both the form and the sense, while the least ideal is keeping neither the form and the sense. When he chooses to keep the form only, he does not pay attention to the sense, and vice versa so that there must be some inaccuracies in the TL. Inaccuracies in the sense will cause the story to be different from what the writer intends to convey to the reader; on the other hand, inaccuracies in the form will lessen the playful or entertaining part of the story, which can make the reader enjoy 
reading the translated version less than enjoying reading the original one.

\section{Methodology}

The paper employs a descriptive qualitative approach in analyzing the data. The data are in the form of language units taken from an English novel as the source text and their translated version in the target text, which is in Indonesian. The paper will focus on language units in the form of phonological play in the SL and in the TL. The data are further analyzed in terms of what kinds of language play are used and how they are translated. Then the translator's strategies are analyzed, whether (1) only the sense is kept or only the form is kept or (2) both the sense and the form are kept or (3) neither the sense nor the form is kept.

\section{FINDINGS AND DISCUSSION}

In this paper there are thirteen data of phonological language play forms in James and the Giant Peach that will be discussed. Furthermore, the strategies the translator uses in translating these forms into the translated version of the novel, James dan Persik Raksasa, are analyzed. Finally, the effects which may occur due to the chosen strategies will also be commented on.

\section{A. Phonological Play and Its Translation}

Phonology is a study of sounds. In the novel there are thirteen data of phonological play, which are classified into three data of alliteration, one datum of consonance, one datum of assonance, four data of rhymes, and four data of onomatopoeia. The three data of alliteration and their translation are as follows:

TABLE I. TRANSLATION OF ALLITERATION

\begin{tabular}{|l|l|l|}
\hline No & \multicolumn{1}{|c|}{ SL } & \multicolumn{1}{c|}{ TL } \\
\hline 1. & $\begin{array}{l}\text { no swing, no seesaw, no } \\
\text { sandpit }\end{array}$ & $\begin{array}{l}\text { tak ada ayunan, tak ada jungkat- } \\
\text { jungkit, tak ada bak pasir }\end{array}$ \\
\hline 2. & curses and cries of pain & $\begin{array}{l}\text { sumpah serapah, dan seruan } \\
\text { kesakitan }\end{array}$ \\
\hline 3. & $\begin{array}{l}\text { I've eaten many strange and } \\
\text { scrumptious dishes }\end{array}$ & $\begin{array}{l}\text { Aku pernah makan segala } \\
\text { makanan }\end{array}$ \\
\hline
\end{tabular}

In the SL datum (1) contains an alliteration, which is "the repetition of the initial consonant in two or more words (Wales, 1994, p. 18). In this datum the consonant $/ \mathrm{s} /$ is repeated at the beginning of the words swing, seesaw, sandpit. The first word, swing, begins with a cluster sound /sw/ actually; yet, the sound $/ \mathrm{s} /$ is still quite dominant in the beginning. In terms of the sense, the words swing, seesaw, and sandpit are equivalent with ayunan, jungkat-jungkit, and bak pasir. Both swing and ayunan refer to "a seat for swinging on, hung from above on ropes or chains." (Hornby, 2010, p. 1512); both seesaw and jungkat-jungkit are "a piece of equipment to play on consisting of a long flat piece of wood that is supported in the middle" (Hornby, 2010, p. 1337); sandpit and bak pasir mean "an area in the ground or a shallow container, filled with sand for children to play in (Hornby, 2010, p. 1308).
Regarding the form, the alliteration in the SL is not translated in the TL. However, it can be seen that the TL has another form of language play, which is assonance, the repetition of vowel sounds (Wales, 1994, p. 18). The data in the TL repeats the vowel sound /a/ in the phrases tak ada ayunan, tak ada jungkat-jungkit, tak ada bak pasir.

Datum (2) of alliteration has the repeated consonant sound $/ \mathrm{k} /$ in the words curses and cries. In the TL the translator decides to keep the sense as she chooses to use the words sumpah serapah, and seruan kesakitan. Based on the dictionary meaning, the word curse and the translated version sumpah serapah mean the same "a rude or offensive word or phrase that some people use when they are very angry" (Hornby, 2010, p. 359). Furthermore, the words cries and seruan are also equivalent in meaning, which is "a loud shout" (Hornby, 2010, p. 354).

Although it does not have the alliteration $/ \mathrm{k} /$, the $\mathrm{TL}$ contains a consonance - the repetition of consonant sounds within a sentence or phrase which do not necessarily have to be located at the beginning of the words ("Consonance", n.d.). In the TL the consonant/s/ is repeated in the words sumpah serapah, seruan, and kesakitan.

In datum (3) of alliteration in the SL there is the alliteration /s/ in the sound clusters /str/ and /skr/ in the words strange and scrumptious. Despite the fact that the sound clusters are not exactly the same, the sound /s/ in the beginning is dominant. In the TL the line "I've eaten many strange and scrumptious dishes" becomes "Aku pernah makan segala makanan", in which the sense is not kept. The words strange, meaning unusual or surprising, especially in a way that is difficult to understand" (Hornby, p. 2010, p. 1474) and scrumptious, meaning "tasting very good" (Hornby, 2010, p. 1327) are inequivalent with segala, which means "all" ("Segala", 2018).

Regarding the form, the TL does not contain alliteration. Yet, it contains an assonance /a/ in the words aku pernah makan segala makanan.

Based on the three data of alliteration and their translation previously described, it is clear that the writer's intention of creating a pleasant sound by using the language play in the form of sound repetition is still kept in the translation, although it is a different type of sound repetition. Besides, it seems that the translator prefers keeping the form to the sense so that in one datum the meaning is slightly inaccurate, but the enjoyment of reading is still kept. The strategy is in line with Delabastita's (1994), in which the witty form is still kept although by using another rhetorical device.

TABLE II. TRANSLATION OF CONSONANCE

\begin{tabular}{|l|l|l|}
\hline No & \multicolumn{1}{|c|}{ SL } & \multicolumn{1}{c|}{ TL } \\
\hline 1. & $\begin{array}{l}\text { punishment and pain, } \\
\text { unhappiness and despair }\end{array}$ & $\begin{array}{l}\text { hukuman dan kesakitan, } \\
\text { ketidakbahagiaan dan kesedihan }\end{array}$ \\
\hline
\end{tabular}

The next type of phonological play is consonance. There is only one datum of consonance in the SL, in which the consonant $/ \mathrm{p} /$ is repeated in the words punishment, pain, unhappiness, and despair. In the TL it is seen that the 
translator keeps the sense as the four nouns in the SL are translated equivalently in the TL. The word punishment is equivalent in meaning with hukuman, which is "the infliction or imposition of a penalty as retribution for an offense" (Hornby, 2010, p. 1189). The equivalence can also be found in the words pain and kesakitan, which mean "mental or emotional suffering" (Hornby. 2010, p. 1057). The words unhappiness and ketidakbahagiaan, which both refer to the state of "being not pleased or satisfied with something" (Hornby, 2010, p. 1628), also show equivalent translation. It is also clear that the translator keeps the sense in the TL in the next words, despair and kesedihan, meaning "the feeling of having lost all hope" (Hornby, 2010, p. 396).

The language play form of consonance is also kept in the $\mathrm{TL}$, with the repetitive sound /k/ in the words hukuman, kesakitan, ketidakbahagiaan, and kesedihan. Thus, in this datum of consonance, the translator has kept both the sense and the form, which makes the writer's intention of producing a pleasant sound still kept and at the same time the meaning can be transferred well to the TL. This is more or less similar to Delabastita's strategy that the repetitive sound form in the $\mathrm{SL}$ is translated into the same type of repetitive sound form in the TL.

TABLE III. TRANSLATION OF ASSONANCE

\begin{tabular}{|l|l|l|}
\hline No & \multicolumn{1}{|c|}{ SL } & \multicolumn{1}{c|}{ TL } \\
\hline 1. & $\begin{array}{l}\text { to baby-sit and sing and knit } \\
\text { and be chaperone }\end{array}$ & $\begin{array}{l}\text { untuk menjaga, merajut, } \\
\text { bernyanyi, dan mengawasi }\end{array}$ \\
\hline
\end{tabular}

The next language play form is assonance, which is the repetition of the same vowel sound in words which end with a different consonant (Wales, 1994, p. 39). The data of assonance found is in the line "to baby-sit and sing and knit and be chaperone", in which the vowel /I/ is repeated in the words baby-sit, sing, and knit. Regarding the sense, it can be seen that the translator keeps the sense quite well in the TL as she translates it into menjaga, merajut, and bernyanyi. To baby-sit means "to take care of babies or children for a short time while their parents are out" (Hornby, 2010, p.89). In the TL it becomes menjaga, which is not inaccurate, although it is more general in meaning. The other two verbs, knit, which is "to make clothes, etc. from wool or cotton thread using two long thin knitting needles or a machine" (Hornby, 2010, p. 824) and sing, meaning "to make musical sounds with your voice in the form of a song or tune" (Hornby, 2010, p. 1385), are perfectly translated into merajut and bernyanyi.

In the TL, the language play form of assonance is still kept, although with a different repetitive vowel sound. In the TL it becomes menjaga, merajut, bernyanyi, which contains the repetition of $/ \mathrm{a} / \mathrm{and} / \mathrm{/} /$ vowel sounds. Therefore, in the datum of assonance the translator has kept both the sense and the form. This means that besides keeping the sense, the translator keeps the effect of language play in the SL, which is creating a pleasant sound. Once again, Delabastita's strategy of keeping the form is applied.
TABLE IV. TRANSLATION OF RHYME

\begin{tabular}{|l|l|l|}
\hline No & \multicolumn{1}{|c|}{ SL } & \multicolumn{1}{c|}{ TL } \\
\hline 1. & $\begin{array}{l}\text { like jellied gnats and } \\
\text { dandiprats and earwigs cooked } \\
\text { in slime }\end{array}$ & $\begin{array}{l}\text { seperti jelly gnat, dandiprat, dan } \\
\text { kuping berkutu }\end{array}$ \\
\hline 2. & $\begin{array}{l}\text { mice with rice. They are really } \\
\text { nice }\end{array}$ & dan tikus tanah - amat renyah \\
\hline 3. & $\begin{array}{l}\text { And scrambled dregs, and } \\
\text { stinkbugs' eggs and hornets } \\
\text { stewed in tar ... }\end{array}$ & $\begin{array}{l}\text { Dan ampas hancur, telur kocok, } \\
\text { dan kerbau rebus aspal }\end{array}$ \\
\hline 4. & pails of snails and lizards' tails & seember siput dan goreng buntut \\
\hline
\end{tabular}

The fourth type of phonological play is rhymes, which refer to the repetition of final syllabic sounds (Wales, 1994, p. 408). In the SL, there are four data of rhymes. The rhyming sound in datum (1) is the sound /æts/ in the words gnats and dandyprats; in datum (2) the sound /aIs/ in mice, rice, and nice; in datum (3) the sound /egz/ in dregs and eggs; in datum (4) the sound /erlz/ in pails, snails, and tails.

When looking at the translation of data (1) in Table IV the words gnats and dandiprats are not translated. The word gnat means "a small two-winged fly that resembles a mosquito" ("Gnat", n.d.). and the word dandiprat means "a little, insignificant, or contemptible person" ("Dandiprat", n.d.). Hence, despite the translatability of these two words, it seems that the translator decides to use loan words in the translation. This leads to the fact that both the sense and form of rhyme in the SL is of course still kept in the TL.

Datum (2), "mice with rice. They are really nice" is translated into "dan tikus tanah - amat renyah." Considering the sense, the datum is not equivalently translated. The word mice is the plural form of a mouse, meaning "a small animal that is covered in fur and has a long thin tail" (Hornby, 2010, p. 965), while tikus tanah is a rodent which resembles a large mouse. Moreover, the word rice is not translated at all, while the word nice, which means "pleasant, enjoyable or attractive" (Hornby, 2010, p. 994), is not translated equivalently into renyah, which means something firm, dry, and brittle ("Renyah", 2018). Regarding the form, the translation in the TL contains a rhyme in the words tanah and renyah, both of which end with the sound /ah/.

The rhyming words in datum (3) dregs and eggs are translated into ampas hancur and telur kocok, which is not equivalent in meaning. The word dregs means "the last part of something" (Hornby, 2010, p. 446) and the word eggs means "a small oval object with a thin hard shell produced by a female bird and containing a young bird; a similar object produced by female fish, insect, etc." (Hornby, 2010, p. 470). Thus, the sense is not perfectly kept in the translation. In the TL, ampas hancur means the ruined residue of something from which the essence has been taken ("Hancur", n.d.), while telur kocok means an egg which is mixed ("Kocok", 2018). Nevertheless, the form of rhyme is still kept in the words hancur and telur, which both end with the same sound /ur/.

The rhyming words in datum (4) "pails of snails, and lizards' tails" are translated into "seember siput dan goreng buntut". The translation has rhyming words in the words siput and buntut. However, the sense is not entirely kept, especially 
in the last part of the line when lizards' tails, which means the lizard's part "that sticks out and can be moved at the back of the body" (Hornby, 2010, p. 1519), is translated into goreng buntut, which means fried tails.

Based on the translation of the four data of rhymes above, it is clear that the translator prefers keeping the form to the sense. The meaning of the line is not the same as in the SL but the effect of the pleasant sound produced by the rhymes is still kept. By keeping the effect of rhymes, the translator does not "sacrifice the fun" (Ushurova, 2013).

TABLE V. TRANSLATION OF ONOMATOPOEIA

\begin{tabular}{|l|l|l|}
\hline No & \multicolumn{1}{|c|}{ SL } & \multicolumn{1}{c|}{ TL } \\
\hline 1. & quack quack quacko & kwak-kwak-kwakau \\
\hline 2. & plop plop plop plop & plop plop plop plop \\
\hline 3. & ping ping ping & tling tling tling \\
\hline 4. & crack & krak \\
\hline
\end{tabular}

The four data in Table V show language play in the form of onomatopoeia, which is "the lexical process of creating words which actually sound like their referent (Wales, 1994, p. 328). The first data of onomatopoeia, "quack quack quacko", refers to the sound of a duck (Hornby, 2010, p. 1197), which is then translated into kwak-kwak-kwakau. In Indonesian the sound of a duck is usually imitated as kwek or $k w a k$. Therefore, in this datum the onomatopoeia is translated by keeping the sense as well as the form.

The next form of onomatopoeia is in datum (2) "plop plop plop plop", which is "a short sound like that of a small object dropping into water" (Hornby, 2010, p. 1123). In the TL, the word used is the same, plop, which is used to imitate the sound of an object falling. In the second datum both the sense and form are kept.

In datum (3) the onomatopoeia "ping ping ping" is used to refer to "a short high sound made when a hard object hits something that is made of metal or glass" (Hornby, 2010, p. 1109). The translation of the onomapoeia in the TL is "tling tling tling". The word tling is not listed in the dictionary as a word imitating a certain sound,. Yet, the final sound /in/ indicates a high-pitched sound produced by an object made of metal or glass being hit. Consequently, in the TL the sense as well as the form of the onomatopoeia can be considered to be kept.

In the last datum the onomatopoeia crack is translated into krak in the TL. Crack refers to "a sudden loud noise" (Hornby, 2010, p. 340), while krak is actually not found in the dictionary. However, it uses the same sound as in the original word, namely $/ \mathrm{kr} /$ and $/ \mathrm{k} /$. Thus, this translation can be considered to have kept the sense and the form.

The translation of the four data of onomatopoeia previously described shows that the translator has succeeded in keeping not only the sense but also the form. Related to the effect of the use of onomatopoeia, which is to give pleasure to the readers (Finch, 1998, p. 39), the translation can still make the readers pleased with the sound produced. The translation of onomatopoeia confirms Delabastita's (1994) opinion that language play form are not untranslatable.

On the whole, the findings of the analysis confirm Delabastita's (1994) and Ushurova's (2013) opinions about translating forms of language play. The translator of James and the Giant Peach has mostly kept the sense and the form in order to keep the effect produced by the phonological play in the TL. When a decision should be made whether to keep the sense or the form, the translator seems to prefer keeping the form.

\section{CONCLUSION}

In the findings of the paper, it can be seen that there are five types of phonological play, which are alliteration, consonance, assonance, rhyme, and onomatopoeia. This suggests that Dahl as the writer is very creative in using words. Besides, considering that the novel is intended for children, the dominant use of phonological play, which involves language play with sounds, is an effective tool to make the novel appeal to children. Dahl seems to perfectly understand that it is not enough for an interesting story for children to rely only on the storyline; the language needs to be as interesting as the storyline as well.

Regarding the distribution of the thirteen data discussed, there are four data each of rhyme and onomatopoeia, three data of alliteration, and one datum each of consonance and assonance. The translation of these data of phonological play shows that the translator keeps the form of them all and she keeps about $70 \%$ of the sense. This suggests that the translator is aware of the importance of the language play form, in this case the sound play. This is a wise decision considering that the target readers of the novel are children who enjoy reading a text having pleasant sounds.

Related to the form of language play that the translator keeps, the data show that actually in the TL the form is sometimes not exactly the same as in the SL. Alliteration in the SL, for example, is translated into assonance in the TL. A rhyme of a certain sound is translated into a rhyme of a different sound. This is understandable because translating phonological play forms is not something simple; thus, when a translator can do something like this, it is regarded as a job successfully done. The translation of the novel also shows that the translator has expressed her appreciation of the witty and beautiful language used by the writer by consistently keeping the forms of the language play.

All in all, translating is a process involving some strategies that a translator should choose in order to produce a good translation. In translating a text, especially that with a unique and great style of writing, a translator should see to it that it is not only the sense that is kept, but also the form or the writer's writing style. Else, the readers of the translated version will not enjoy the novel as much as they should.

The analysis itself has several limitations. One of them is the fact that the analysis only focuses on the phonological play. In the future research the analysis can be extended to the translation of the morphological, syntactic, and semantic play as Roald Dahl is also great in those types of language play. 
Moreover, this paper discusses the translation of language play forms only in one of Dahl's children's novels. It would be much better if in the future the discussion can be expanded to the other novels. Contrastive $\mathrm{n}$ comparative studies between R. Dahl's and other writers' novels or between one version of translation published by one publisher and the other version published by another will also be of much significance.

\section{References}

Chusfani, P.D. (2010). James dan persik raksasa. (Roald Dahl, Trans.). Jakarta: PT. Gramedia Pustaka Utama. (Original work published 1961)

Cook, G. (2000). Language play, language learning. Oxford: Oxford University Press.

Crystal, D. (1998). Language play. London: Penguin Books Ltd.

Finch, G. (1998). How to study linguistics. Houndmills: Palgrave Macmillan.

Hatim, B. \& Munday, J. (2004). Translation: An advanced resource book. New York: Routledge.

Hornby, A. S. (2010). Oxford advanced learner's dictionary $8^{\text {th }}$ edition. Oxford: Oxford University Press.

Tanto, T. (2010). Implikasi pragmatis dari permainan bahasa dalam fiksi berbahasa Inggris untuk anak-anak. (Unpublished doctoral dissertation). Universitas Padjadjaran, Bandung.

Consonance. (n.d.). In Literary devices. Retrieved from https://literarydevices.net/consonance/
Dandiprat. (n.d.). In Oxford dictionaries. Retrieved from https://www.merriam-webster.com/dictionary/dandiprat

Delabastita, D. (Jan., 1994). Focus on the pun: wordplay as a special problem in translation studies. Target. doi: 10.1075/target.6.2.07del. Retrieved from https://www.researchgate.net/publication/263114479

Gnat. (n.d.). In Oxford dictionaries. Retrieved from https://en.oxforddictionaries.com/definition/gnat

Hancur. (2018). In Kamus besar bahasa Indonesia online. Retrieved from https://kbbi.kemdikbud.go.id/hancur

Kocok. (2018). In Kamus besar bahasa Indonesia online. Retrieved from https://kbbi.kemdikbud.go.id/kocok

McQuarrie, E.F. \& Mick, D.G. (Mar., 1996). Figures of rhetoric in advertising language. The Journal of Consumer Research, 22 (4), 424-438. doi: 10.1086/209459. Retrieved from http://www.uky.edu/ ngrant/CJT780/readings/Day\%205/ McQuarrieMick1996.pdf

Renyah. (2018). In Kamus besar bahasa Indonesia online. Retrieved from https://kbbi.kemdikbud.go.id/renyah

Segala. (2018). In Kamus besar bahasa Indonesia online. Retrieved from https://kbbi.kemdikbud.go.id/segala

Ushurova. S. (2013). Translate the pun. sacrifice the fun: a comnarative case studv of the Dutch Subtitled wordnlv in an enisode of The Persuaders!. (Unnublished thesis). Geassocieeerde Faculteit Toegepaste Taalkunde. Retrieved from https://www.ethesis.net/Wordplay/Wordplay.pdf 